\section{policy \\ and \\ society}

Policy and Society $\mathrm{xxx}(2010) \mathrm{xxx}-\mathrm{xxx}$

\title{
Social enterprise in Europe: At the crossroads of market, public policies and third sector
}

\author{
Jacques Defourny ${ }^{\mathrm{a}}$, Marthe Nyssens ${ }^{\mathrm{b}, *}$ \\ ${ }^{a}$ EMES and University of Liege, HEC-ULg Department of Economics and Centre for Social Economy, Belgium \\ ${ }^{\mathrm{b}}$ EMES and Catholic University of Louvain, Department of Economics and CIRTES, IRES, 3 place Montesquieu, 1348 Louvain-la-neuve, Belgium
}

\begin{abstract}
Over the last 15 years, the concept of social enterprise has been raising an increasing interest in various regions of the world. In the present paper, we describe, first, the European historical landscapes in which the concept of social enterprise took root. In the second part, we analyze the various public policies introduced in several European countries. In the third part, we analyse the logics of financing of social enterprises. Based on the EMES conception of social enterprise, we underline the "hybridization" of their resources. European social enterprises indeed, most often, combine income from sales with public subsidies linked to their social mission and private donations and/or volunteering. This clearly contrasts with a strong US tendency to define social enterprises as non-profit organizations more oriented towards the market and developing "earned income strategies" as a response to decreasing public subsidies and to the limits of private grants from foundations.
\end{abstract}

(C) 2010 Policy and Society Associates (APSS). Elsevier Ltd. All rights reserved.

Keywords: Social enterprise; Financing; Legal frameworks; Public policies; Economic risk; Europe

\section{Introduction}

Over the last 15 years, the concept of social enterprise has been raising an increasing interest in various regions of the world, first in Europe and the United States and more recently in other regions such as Eastern Asia (especially Japan and South Korea) and Latin America.

In Europe, it seems clear that the notion of social enterprise first appeared in Italy in the late 1980s, but it really began to be used at the European level in the mid 1990s, especially through the works of the EMES European Research Network. ${ }^{1}$ As will be shown in the following pages, although the concept itself has not gained the same recognition in all European countries (and is even still poorly understood in several of them), the field realities that it aims to highlight

\footnotetext{
* Corresponding author. Tel.: +32 10473992 .

E-mail address: marthe.nyssens@uclouvain.be (M. Nyssens).

${ }^{1}$ The letters EMES stood for "EMergence des Enterprises Sociales en Europe", i.e. the title in French of the vast research project carried out from 1996 through 2000 by the network. The acronym EMES was subsequently retained when the network decided to become a formal international association and went on to conduct other research projects on social enterprises and, more broadly, on the third sector as a whole. Nowadays, the EMES European Research Network brings together ten university research centers and individual researchers specialized in these fields throughout Europe. These research works, mainly supported by the European Commission's Research Directorate-General, resulted in a first book entitled The Emergence of Social Enterprise (Borzaga \& Defourny, 2001), a wide series of EMES Working Papers (available on www.emes.net) and a second book Nyssens (2006), focusing on work integration social enterprises. The EMES Network has also extended its research area to Eastern and Central European countries, including some countries of the Community of Independent States, such as Ukraine (Borzaga \& Spear, 2004; EMES, 2008).
} 
are developing almost everywhere and increasing research efforts are being made to analyse them. International literature on this theme is thus now developing significantly (Borzaga \& Defourny, 2001; Mair, Robinson, \& Hockerts, 2006; Nicholls, 2006; Kerlin, 2009).

Within this context, the present paper is structured along the following lines. First, we describe the European historical landscapes in which the concept of social enterprise took roots. In the second part, we analyze the various public policies introduced in several European countries to foster social enterprises. Indeed, in the European context, the process of institutionalization of social enterprises has often been closely linked to the evolution of public policies. In the third part, we analyse the logics of financing of social enterprises especially underlining the "hybridization" of their resources in Europe. As we will see, the way social enterprise are financed is a critical issue which reflects both quite distinct socio-economic contexts and the very conceptions of social enterprise embedded in such contexts, especially when contrasting US and European landscapes.

\section{The socio-economic context of the European debate}

In Europe, the concept of social enterprise made its first appearance around the year 1990, with the identification of entrepreneurial dynamics, at the very heart of the third sector, which arose primarily in response to social needs that had been inadequately met, or not met at all, by public services or for profit enterprises. It is crucial to note here that, in contrast with the US tradition, most scholars in the European tradition see the third sector as bringing together cooperatives, associations, mutual societies and increasingly foundations, or in other words, all not-for-profit organizations (organizations not owned by shareholders) that are labeled the "social economy" in some European countries (Evers \& Laville, 2004). ${ }^{2}$

To make things as clear as possible from the outset, such a view of social enterprise as a new dynamics suggests that the very notions of social enterprise and social entrepreneurship should be used first of all as a conceptual and an analytical framework which sheds light on new evolutions within the third sector: either the setting up of brand new organizations or the reshaping of existing organizations through entrepreneurial dynamics. This also means such an approach does not necessarily allow drawing clear-cut boundaries and counting organizations of a "social enterprise subsector". As we will see latter, there exist other approaches which often try to encompass a whole set of organizations likely to be described as social enterprises. This is particularly the case when specific laws define social enterprise, often to use the latter as an instrument to implement certain programs of public policies. However, when looking closely at such contexts, it clearly appears that many initiatives not covered by such definitions may also be analyzed as social enterprise. So it is rather easy to argue that building statistics about a "social enterprise sector" is less meaningful than complementing existing approaches (for example the NPO approach) with a social enterprise framework stressing the entrepreneurial dynamics shaping such entities.

A second major point to be underlined from the outset is that the organizational forms, the social or societal objectives and the fields of activity of social enterprises may vary across countries and within a given country. As we will see, the objective of work integration of vulnerable groups attracts much attention and policy measures but social enterprises may also be set up to foster for example local development, environmental activities, provision of social and personal services, ethical finance, fair trade, cultural creation, and international development.

Beyond such a diversity of objectives and fields, some driving forces clearly played major roles in European socioeconomic contexts. More particularly, the persistence of structural unemployment in many European countries, the need to reduce state budget deficits, the need for more active integration policies raised the question of how far the third sector could help to meet these challenges. Social actors, such as social workers and associative militants, were facing a lack of adequate public policy schemes to tackle the increasing exclusion of some groups (such as long-term unemployed people, low-qualified people, people with social problems) from the labour market or more generally from society.

Such an overall context was common to all countries in the 1980s and 1990s and served as a background for most new entrepreneurial dynamics which emerged in the third sector as responses to those challenges. However the forms of such initiatives varied according to the specificities of the different European models.

\footnotetext{
${ }^{2}$ For a discussion of this concept see Defourny (2001).
} 
We use the classical Esping-Andersen typology (1999) to identify the different configurations of these dynamics. Even if this typology is no longer sufficient to characterize the welfare evolutions in the European landscape (Evers, 2010), it still remains a good starting point to understand the role of third sector in a variety of European countries in the 1980s (Salamon et al., 2004) and therefore the different milieus in which social enterprises dynamics took root.

Esping-Andersen distinguishes three major types of welfare states, connecting these with variations in the historical development of different Western countries. A 'liberal' or 'Anglo-Saxon' regime is one in which the 'market' is responsible for providing 'welfare' services. A socio-democratic regime offers a wide spectrum of welfare services organized by the State on a universal basis. According to Esping-Andersen, conservative or corporatist welfare states are concerned with maintaining order and status. In order to accomplish this goal, social insurance funds were set up with a view to reward work performance and status. In these countries, public insurance funds and welfare services were established and operated either by the government or by non-profit organizations regulated by the state.

\subsection{The corporatist countries}

In the countries with a corporatist tradition (namely Belgium, France, Germany, and Ireland ${ }^{3}$ ), associations, mainly financed and regulated by public bodies play an important role in the provision of social services (Salamon et al., 2004).

During the 1980s, public bodies faced high rates of unemployment and a crisis in public finances. New entrepreneurial dynamics could be identified in associations which were pioneers in promoting the integration of unemployed persons through a productive activity. It could be considered that these pioneering associations actually implemented active labour market policies before the latter came into institutional existence (Defourny, Favreau, \& Laville, 1998). Active labour policies aimed to integrate the unemployed into the labour market through programs such as professional training or job subsidies rather than relying exclusively on passive labour market policies based on a system of cash benefits to the unemployed.

Within this field of active labour market policies, we can spot in these corporatist countries a large "second labour market programme", offering intermediate forms of employment. Such a programme was based on the observation that, on the one hand, a number of unsatisfied social needs existed and, on the other hand, a large number of people were unemployed. These programs thus tried to encourage the creation of new jobs in areas where they could satisfy social needs, as a means of both creating jobs for unemployed persons and curbing mainstream social spending. With the institutionalisation of the second labour market program, associations have increasingly constituted a tool for its implementation (Lemaitre, Laville, \& Nyssens, 2006).

This kind of public scheme fostered the trend toward a more productive role of associations and entrepreneurial dynamics. In countries such as France and Belgium, these dynamics were explicitly located inside the third sector, which was referred to as the "social economy" (économie sociale) or the "solidarity economy" (économie solidaire).

\subsection{The socio-democratic countries}

The Nordic countries (Sweden, Norway, Denmark) are characterised by the highest level of welfare expenditures in Europe and correspond to the "social democratic" group of Esping-Andersen's typology. In these countries, there is traditionally a division of tasks between the state, the business community, and associations (Stryjan, 2006). The welfare state is expected to deliver welfare, the business sector ensures the production, the accumulation, and the creation of jobs, and associations focus on the articulation of interests and the shaping of the broad societal agenda. These countries also have a strong tradition of a co-operative movement, with, inter alia, workers or farmers cooperatives (Hulgård \& Bisballe, 2004).

In the 1980s, in a context characterized by the emergence of new challenges, new dynamics emerged in this cooperative sector. In Sweden, the first new worker co-operatives were initiated in the wake of the psychiatric care reform of 1989 (that phased out large closed-environment mental health institutions) by actors within the field of

\footnotetext{
${ }^{3}$ The inclusion of Ireland in this first group may seem rather odd. However, Ireland has one of the highest shares of employment in the non-profit sector, and the latter relies heavily on public funding. Actually, some research has shown that Ireland is a borderline case between the "liberal" and the "corporatist" state (Hicks and Kenworthy, 2003).
} 
mental care: care personnel, patients and ex-patients (Stryjan, 2004). As the expansion of the Swedish public childcare sector slowed down during the 1980s, parent co-operatives experienced a rapid growth, in the framework of a search for new pedagogical models (Pestoff, 2004).

With the emergence of these new forms of co-operatives, a new actor appeared in the landscape of the third sector with a clear role in the production of welfare which, until than, was the sole responsibility of the state.

\subsection{The liberal countries}

The UK is traditionally viewed as emblematic of the liberal model. In this configuration, a lower level of government social spending is associated with a relatively large voluntary sector relying mostly on private resources (Salamon et al., 2004). The situation in the UK, though, could be described as "mixed": indeed, the experience of the two World Wars led national public authorities to develop various social programs with universal coverage, in the framework of which charities were supported through public subsidies (Lewis, 1999).

This landscape was challenged in the 1970s and 1980s by a new public management approach that stressed quasimarket mechanisms to increase efficiency in service provision (Pollitt, 2007). Within a quasi-market, the state still contributes to the financing and the regulation of the service but provision is open to all kinds of organisations: public sector, third sector and for-profit sector providers compete in the market. The UK community care reform of the early 1990s was emblematic of this trend; it was hoped that this reform of public policies would allow the public sector bureaucracy to be reduced and lead to the adoption of the discipline and rigor of the market place (Netten et al., 2004). A new role was assigned to local authorities which led to the exercise of their purchasing power through contracting out the provision to the "independent sector". The focus was put on private providers, be they for-profit or associations (the voluntary sector).

In this context, the types of relationships between the state and the voluntary sector were at stake. It seems that what was challenged was not the level of social expenditures but rather the instruments through which the government supported third sector organizations: public money took the form of contracts and third-party payments instead of grants. This trend clearly fostered the entrepreneurial dimension of associations.

\subsection{The southern European countries}

Scholars are arguing if it is relevant to distinguish a specific "welfare regime" among the European Mediterranean countries (Esping-Andersen, 1999). However, it is recognized that welfare spending in general is lower, in Southern European countries, such as Spain, Italy or Portugal, and that the provision of social services financed by the state, in particular, is underdeveloped. Families are considered the key actor in welfare provision (Bettio \& Plantenga, 2004). Historically, Church-related charitable organizations have also played a central role as providers of social services, but this responsibility has been controlled or limited by the state in the 20th century, especially during the fascist period, in order to control civil society. This explains why, in Italy, for example, in the 1970s, non-profit organisations were relatively few, and they were merely confined to advocacy activities (Borzaga, 2004). Countries as Spain and Italy are also characterized by a strong co-operative tradition.

In this context, it is not surprising that in the late 1980s, new co-operative-like initiatives emerged in Italy to respond to unmet needs, especially in the field of work integration - as some groups were increasingly excluded from the labour market - as well as in the field of personal services - in a context of rapid aging of the population and changes in family structures. In contrast to traditional co-operatives that were primarily oriented toward members' interests, these initiatives were serving a broader community or external "target groups" and putting greater emphasis on the dimension of general interest. They also differed from traditional co-operatives in that they often combined different types of stakeholders in their membership (paid workers, volunteers and other supporting members), whereas traditional co-operatives are usually single-stakeholder organizations (Borzaga \& Mittone, 1997).

Although related concepts may have been used elsewhere previously, the concept of "social enterprise" as such seems to have first appeared in Italy where it was promoted through a journal launched in 1990 and entitled Impresa sociale. The concept was introduced at that time to designate these pioneering initiatives for which the Italian Parliament created the legal form of "social co-operative" 1 year later. In 1991, the Italian parliament passed a law creating a specific legal form for "social co-operatives" and the latter went on to experience an extraordinary growth. 
To sum up, we could say that various driving forces could be observed in Europe, which underpin the development of innovative and entrepreneurial third sector organisations. These latter organisations paved the way for an increased explicit reference to social enterprise. It is clear that changes in public funding of the third sector played an important role in shaping new attitudes and strategies for third sector organizations as was the case for the non-profit sector in the US in the 1980s. The US scene however was marked by the fact that the share of public support to non-profit organisations decreased, while the share of commercial income increased significantly (Kerlin, 2006). In Western Europe, it was the forms - rather than the volume or the share - of public funding that were transformed. In the corporatist countries, secondary labour market programs fostered entrepreneurial associative dynamics. In contrast the development of quasi-markets in 'liberal' countries fostered contractual relations between associations and public authorities in a more competitive environment. In both Socio-democratic and Mediterranean countries; third sector organisations and more specifically co-operatives appear as emerging welfare service providers.

\section{Public policies and social enterprises}

In several countries, these innovative third sector organisations were set up without any legal framework and sometimes outlawed completely. Such organisations built platforms and federative bodies to advocate for a better recognition of their specificities. As a result, in the political arena, laws were passed to promote new legal forms and public schemes, better suited to social enterprises.

\subsection{The development of new legal forms across Europe}

The pioneering Italian law adopted in 1991 distinguishes between two types of social co-operatives: those delivering social, health and educational services, called "A-type social co-operatives" and those providing work integration for disadvantaged people, referred to as "B-type social co-operatives". From the second half of the 1990s, several other European countries introduced new legal forms reflecting the entrepreneurial approach adopted by this increasing number of "not-for-profit" organizations, even though the term of "social enterprise" was not always used as such in the legislation (Defourny \& Pestoff, 2008). Sixteen new laws have been identified across European countries (Roelandts, 2009). In France, Portugal, Spain and Greece, these new legal forms were of the co-operative type. Some other countries such as Belgium, the UK and Italy (with a second law passed in 2006) chose more open models of social enterprise rather than ones based solely on the co-operative tradition. The Belgian "company with a social purpose" and the Italian law on social enterprise define a label which crosses the boundaries of all legal forms and can be adopted by various types of organization (not only co-operatives and non-profit organizations, but also investorowned organizations, for instance), provided they define an explicit social aim and that they are not dedicated to the enrichment of their members.

Of course, there exists a great diversity beyond this basic dichotomy. For instance, the French and Italian legal forms could be qualified as "multiple stakeholders forms" as they bring different stakeholders (employees, users, volunteers...) to work together on a given social purpose project.

In the UK, the Parliament approved a law creating the "community interest company" in 2004 but 2 years earlier, the British government also put forward a definition of social enterprise as "a business with primarily social objectives whose surpluses are principally reinvested for that purpose in the business or in the community, rather than being driven by the need to maximize profit for shareholders and owners" (DTI, 2002).

\subsection{A variety of other legal forms adopted by social enterprises}

Although newly created legal forms may prove to be important tools in some countries, most social enterprises across Europe, even in countries where these new legal forms have emerged, still adopt legal forms that have existed for a long time, namely those of association, co-operative, company limited by guarantee or by share, Industrial and Provident Societies in the UK, etc. More generally, social enterprises are established as associations in those countries where the legal form of association allows a significant degree of freedom for selling goods and services. In countries where associations are more limited in this regard, social enterprises are set up, more often, under the legal form of cooperatives. And in some cases, social enterprises adopt traditional business legal forms. 
In some European countries, the concept of social enterprise is not part of the political agenda nor of the academic discourse outside a very small circle of experts; this is particularly the case in Germany. The main reason for this probably lies in the fact that the German socio-economic model is based on a wide social partnership agreement around the concept of "social market economy", understood as a specific articulation between the market and the state to foster socio-economic development. Within such a model, the specific roles of social enterprises - or the social economy as a third sector - are particularly difficult to highlight. Although there exist plenty of not-for-profit organizations characterized by an entrepreneurial approach and addressing emerging social needs, these organizations are not considered as making up a distinct group; they seem to be "split up" in a variety of different "milieus", each with its own identities.

\subsection{Public schemes targeting work integration social enterprises}

Social enterprises may be active in a wide spectrum of activities, as the "social purpose" may refer to many different fields. However, one major type of social enterprise is clearly dominant across Europe, namely "work integration social enterprises" (WISEs) (Nyssens, 2006). The main objective of work integration social enterprises is to help low-qualified unemployed people, who are at risk of permanent exclusion from the labour market. WISEs integrate these people into work and society through a productive activity. ${ }^{4}$

In many countries, besides the creation of new legal forms, the 1990s have seen the development of specific public programs targeting social enterprise in the field of work integration. ${ }^{5}$ Indeed, WISEs have increasingly represented a tool for implementing active labour market policies. In several countries, they have really become a "conveyor belt' of such policies. In France, for instance, 2300 registered structures were providing work-integration services through public schemes and employed some 220,000 salaried workers in 2004.

In a number of European countries, the development of specific public schemes targeted to this type of social enterprise has even led to the concept of social enterprise being systematically associated with such employment creation initiatives. The Finnish Act on Social Enterprise (2003) is emblematic of such a trend, as it reserves this term to the field of work integration. According to this Act, a social enterprise, whatever its legal status, is a market-oriented enterprise created for employing people with disabilities or long-term unemployed. ${ }^{6}$ The Polish act on social enterprise is specifically intended for the work integration of particular needy groups (such as ex-convicts, long-term unemployed, disabled persons and former alcohol or drug addicts). And Spain's national Parliament voted a law, in 2007, on work integration enterprises. It should be noted however that these different legislations do not define any new legal form; they rather create a tool like an official register for social enterprises.

In several other European countries, even when the term of social enterprise is still relatively absent from mainstream policy, it also appears, when used, as associated with the issue of active labour market policies. In Portugal, for instance, there is an on-going debate about the role of third sector organisations when they support the creation of integration companies in the "social employment market", which aims to reintegrate disadvantaged persons through work. In Sweden, the term "social co-operative" has become synonymous with "work integration social enterprise", even though the Swedish landscape is also characterized by the development of social entrepreneurial dynamics in the field of personal services, for example under the form of parent or worker cooperatives and voluntary (commonly multi-stakeholder) associations. Social enterprise as a concept is slowly entering the Danish discourse on social cohesion (Hulgård \& Bisballe, 2004), but it has primarily been used so far as part of an active labour market policy, with an ambition to make traditional enterprises - and especially small and medium enterprises (SMEs) - more socially responsible in matters of integration of unemployed persons into the labour market.

The recognition, by public authorities, of the mission of work integration performed by social enterprises allows the latter, in most cases, to access public subsidies that (although remaining limited) are more stable. However, these subsidies are often only temporary; they are usually granted to launch an initiative and to compensate for the

\footnotetext{
${ }^{4}$ See also Davister et al. (2004).

5 Those public programs sometimes impose a specific legal form to be eligible. In other cases, they do not do so.

${ }^{6}$ It has to be noted that, probably due to the limited extent of benefits linked hereto, only very few organizations in Finland have decided to register as social enterprises so far less than 200 at the end of 2008.
} 
"temporary unemployability" of the workers. Such measures are in fact intended only to facilitate the transition from unemployment to the "first" labour market. In some cases (like under the Finnish Act), social enterprises are only eligible to active labour programs just as any other type of enterprise hiring employees with the required profiles.

While recognising and supporting WISEs, public policies also influence the objectives of these organisations, which may change over time, through a process of institutionalisation. This appears clearly when analyzing the philosophy of the innovative social enterprises which emerged in the 1980s. The key issue then was the empowerment and integration of excluded groups through their participation in enterprises whose aim was to offer disadvantaged workers a chance to reassess the role of work in their lives and to recover control over their own personal project. Such a conception implied not only giving an occupation to these persons, but also developing specific values, for example through democratic management structures in which the disadvantaged workers were given a role, and/or through the production of goods and services generating collective benefits (such as social services or services linked to the environment) for the territory in which these social enterprises were embedded. Getting workers back into the " first" labour market was thus not the priority of these pioneering WISEs. However, the progressive institutionalization and professionalization of the field over the years, through public schemes increasingly linked to active labour market policies, generated strong pressures to make the social mission instrumental to the integration of the disadvantaged workers into the labour market. This explains why some pioneering initiatives chose not to use WISE-specific public schemes; this is for example the case of the "local development" initiatives in Ireland, which did not make use of the "social economy" framework (O'Shaughnessy, 2006). It should be noted too that, while public schemes have encouraged some initiatives, they sometimes excluded others (such as some WISEs characterized by a self-help dynamic in France).

\subsection{Public policies of the European Union}

What is the role of the European Union, if any, in supporting the development of these social enterprises? An analysis in the field of WISEs shows that the share of financing that comes from the European Union is quantitatively low, mainly coming from the European Social Fund (Nyssens, 2006). Although quantitatively low, European subsidies have in some cases constituted an important factor in the emergence and development of social enterprises, sometimes opening new channels of resource mobilisation at the national level. This kind of support "has either helped to create the conditions for the emergence of new social enterprises or has afforded existing enterprises the opportunity to broaden or consolidate their activities through participation in such programmes" (O'Hara, 2001, p. 156).

The influence of the European Commission also appears through the elaboration of the 'National Action Plans for Employment', in which active labour market policy recommendations occupy a major place and explicit reference is sometimes made to social enterprises in the field of work integration. This has contributed, in some countries (such as Portugal or Ireland), to the development of public schemes for WISEs.

Another key area where the influence of the European Commission is central, is the regulation of public contracts. Indeed, contracting the provision of goods or services with (local) public authorities is a key resource for social enterprises (Gardin, 2006). This area is strongly regulated by European law. Under certain thresholds defined by European legislation, public bodies (usually at the local level) may simply "privilege" social enterprises in order to support the latter and their social mission; in the case of purchases over these threshold amounts, specific rules must be respected, but these rules do not exclude the possibility of taking into account social dimensions in the procedures for the award of public contracts. Indeed, two award criteria are allowed: public authorities can award a contract to the tender with "the lowest price" (i.e. the bid with the lowest price, for the required level of quality, is chosen) or they can choose to award the contract to "the most economically advantageous tender", i.e. take into consideration criteria other than price alone (such as social or environmental criteria) in their purchasing decision. They can for example introduce social clauses regarding the integration of disadvantaged workers or a requirement to make services available for specific target groups or communities.

Italy provides the oldest example of such practices: as early as 1991, a law was passed in this country to reserve certain public contracts to social co-operatives. Although this law had to be re-designed following objections from the European Commission alongside its competition policy, such a possibility has been maintained and remains a key tool. In many other countries the legal framework regulating public procurement is less favourable to social enterprises. For instance, the tender regime implied by the Swedish Law on Public Procurements prevents authorities from considering 
social factors; the Swedish interpretation of EU public procurement legislation does not allow for preferred treatment for social enterprises. The same situation prevails in Ireland, the United Kingdom, Portugal and Spain. But legislation is evolving in other countries (such as Belgium and Finland), which are considering introducing social clauses into public tenders. Indeed, national and regional practices in this matter are relatively diverse across the European Union. Competing in the market with for-profit companies solely on the basis of financial criteria often appears difficult for social enterprises which often bear costs which are externalized by traditional companies, and some of them therefore request that public authorities take their social dimension into account when awarding public contracts. This is clearly an important debate for the future of social enterprises across Europe.

More broadly, the access to specific public supports is at the very heart of discussions about "services of general interest" (Huber et al., 2008). Recent debates at the EU level tend to impose norms that disregard the diversity of the forms of enterprise and to only consider private for-profit firms and public institutions as the relevant actors despite the important tradition of social economy in various European countries. The recognition of this diversity appears as a key challenge in the coming years.

\section{Financing social enterprise: where schools of thought may diverge}

Social enterprises are generally viewed as organizations characterized by a significant level of economic risk. Stressing the latter is even more important when one speaks of (social) entrepreneurship, as entrepreneurs are required to look for resources (and to bear the risk of not finding them) needed for those innovations and those "new combinations" they bring about according to Schumpeter. Moreover, to be successful in bearing such risks over a significant period means achieving economic sustainability.

For most people in the business community as well as in the eyes of the general public, the very idea of economic risk tends to be associated with the market and the pressure of competition which can lead to losing customers, selling at prices not covering the costs or even going into bankruptcy. Along such lines, the more its productive activity is oriented to the market, the more a social enterprise appears to bear economic risks and to deserve being called an enterprise, not just an organization.

While comparing the various schools of thought on social enterprise, we have shown elsewhere how such a conception is linked to a specific school of thought that could be named as the "earned income" school (Defourny \& Nyssens, 2010). According to this perspective, a social enterprise can be defined as an organisation that trades for a social purpose, a view which is mainly rooted in the context of the American non-profit sector, confronted by a decrease of public grants and therefore looking for alternative sources of income (Kerlin, 2006). Being a social enterprise thus means relying mainly on market resources through earned-income business activities undertaken by a non-profit organization to generate revenue in support of its charitable mission (Social Enterprise Alliance ${ }^{7}$ ).

For the authors belonging to that school, the economic risk tends to be correlated with the amount or the share of income generated through trade. Such a vision is shared by some European policies, which tend to require a market orientation for social enterprises. In the United Kingdom, for example, social enterprises are seen first and foremost as businesses (see above). The Finish Act on social enterprise and the social economy program in Ireland also describe these organisations as market-oriented enterprises. Moreover, many Italian social co-operatives are financed through contracts which are passed with the public authorities in a more or less competitive market.

However, this conception of economic risk is not shared by all schools of thought in the field of social enterprise and entrepreneurship. Even in the United States where the "earned income" conception of social enterprise is dominating, there are other views which have a strong influence. More particularly, the "social innovation" school of thought mainly stresses innovative initiatives launched by social entrepreneurs to address social or societal challenges. Organizations such as Ashoka and several foundations as well as Dees (1998) clearly belong to that school for which outcomes are more important than incomes and the centrality of the social mission implies a very specific mix of human and financial resources. In other words, social entrepreneurs have to explore all types of resources from donations to commercial revenues allowing them to pursue their social mission.

\footnotetext{
${ }^{7}$ As the Social Enterprise Alliance defined the social enterprise on its website (www.se-alliance.org) for a long period of time. Social enterprise is now defined as follows on its homepage: "An organization or venture that advances its social mission through entrepreneurial, earned income strategies".
} 
Although rooted in a European and quite different context, the approach developed by the EMES European Research Network differs strongly from the "earned income" school of thought and proposes another perspective on the issues of financing and economic risk. ${ }^{8}$

\subsection{The EMES conception of social enterprise and economic risk}

Starting from an inductive perspective, the EMES Network started its reflexion with the identification of new entrepreneurial dynamics at the very heart of the third sector in spite of the great diversity of the latter across national socio-economic contexts.

Through a major research project financed by the European Commission and covering 5 years (1996-2000), scholars from all 15 countries which formed the EU at that time tried to analyse how social enterprises were emerging in their respective national contexts. Key features of their common approach included the fact that it was derived from extensive dialogue among several disciplines (economics, sociology, political science and management) as well as among the various national traditions and sensitivities across the European Union.

Moreover, guided by a project that was both theoretical and empirical, the EMES Network preferred from the outset the identification and clarification of indicators over a concise and elegant definition of social enterprise. Most importantly, such indicators were never intended to represent the set of conditions that an organization should meet to qualify as a social enterprise. Rather than constituting prescriptive criteria, they describe an "ideal-type" in Weber's terms, i.e. an abstract construction that enables researchers to position themselves within the "galaxy" of social enterprises. In other words, they constitute a tool, somewhat analogous to a compass, which helps the researchers locate the position of the observed entities relative to one another.

To reflect the economic and entrepreneurial dimensions of initiatives, four criteria have been put forward:

(a) A continuous activity producing goods and/or selling services

Social enterprises, unlike some traditional non-profit organizations, do not normally have advocacy activities or the redistribution of financial flows (as, for example, many foundations) as their major activity, but they are directly involved in the production of goods or the provision of services to people on a continuous basis. The productive activity thus represents the reason, or one of the main reasons, for the existence of social enterprises.

(b) A high degree of autonomy

Social enterprises are created by a group of people on the basis of an autonomous project and they are governed by these people. They may depend on public subsidies but they are not managed, be it directly or indirectly, by public authorities or other organizations (federations, private firms etc.). They have both the right to take up their own position ("voice") and to terminate their activity ("exit").

(c) A significant level of economic risk

Those who establish a social enterprise assume totally or partly the risk inherent in the initiative. Unlike most public institutions, their financial viability depends on the efforts of their members and workers to secure adequate resources.

(d) A minimum amount of paid work

As in the case of most traditional non-profit organizations, social enterprises may also combine monetary and non-monetary resources, voluntary and paid workers. However, the activity carried out in social enterprises requires a minimum level of paid workers.

To encapsulate the social dimensions of the initiative, five criteria have been proposed:

1. An explicit aim to benefit the community

\footnotetext{
${ }^{8}$ There are also clear divergences between the social innovation school and the EMES approach, especially as to governance issues (Defourny \& Nyssens, 2010). 
One of the principal aims of social enterprises is to serve the community or a specific group of people. In the same perspective, a feature of social enterprises is their desire to promote a sense of social responsibility at the local level.

2. An initiative launched by a group of citizens

Social enterprises are the result of collective dynamics involving people belonging to a community or to a group that shares a well-defined need or aim; this collective dimension must be maintained over time in one way or another, even though the importance of leadership often embodied by an individual or a small group of leaders - must not be neglected.

3. A decision-making power not based on capital ownership

This criterion generally refers to the principle "one member, one vote" or at least to a decisionmaking process in which voting power is not distributed according to capital shares on the governing body which has the ultimate decision-making rights. Although the owners of capital are important when social enterprises have equity capital, the decision-making rights are generally shared with the other stakeholders.

4. A participatory nature, which involves various parties affected by the activity

Representation and participation of users or customers, influence of various stakeholders on decision-making and a participative management are often important characteristics of social enterprises. In many cases, one of the aims of social enterprises is to further democracy at the local level through economic activity.

5. A limited profit distribution

Social enterprises not only include organizations that are characterized by a total nondistribution constraint, but also organizations which - like co-operatives in many countries may distribute profits, but only to a limited extent, thus allowing to avoid a profit-maximizing behaviour.

Source: Defourny (2001)Defourny (2001, pp. 16-18).

\subsection{Economic risk and resource mix}

For the EMES conception, to bear economic risks does not necessarily mean that economic sustainability must be achieved only through a trading activity; it rather refers to the fact that those who establish the enterprise assume the risk of the initiative. An economic risk means that the financial viability of social enterprises depends on the efforts of their members to secure adequate resources for supporting the enterprise's social mission. These resources can have a hybrid character and may come from trading activities, from public subsidies or from voluntary resources.

EMES undertook a major research program in 2001, to explore more deeply the socio-economic rationale underpinning social enterprise, based on a sample of 162 work integration social enterprises, located in 11 European countries $^{9}$ (Nyssens, 2006). One of the core hypothesis put forward by this research project was that social enterprises mobilise different kinds of market and non-market resources to sustain their mission; by following Polanyi (1944) and his 'substantive approach' to the economy, the hypothesis that social enterprises mix the economic principles of market, public redistribution and reciprocity was put forward. The results of the research project confirmed that the economic dimension of social enterprises does not necessarily mean that they achieve economic sustainability through resources generated by commercial activities (Gardin, 2006).

European Union WISEs rather show a particular capacity to articulate resources in various ways, in order to pursue their complex set of objectives. Moreover, it appears that WISEs do not rely only on a mix of "pure" market- and redistribution-based resources; they are the scene of a more complex hybridisation, built upon four types of economic relationship: the market and redistribution, but also the "socially motivated sales" which take into account the social goals of WISEs, i.e. the integration of marginalized persons in the enterprise (as in some cases in which public authorities contract out the provision of goods or services,) and reciprocity (an example of a reciprocity-based resource is provided by volunteering). The sales of goods and services represent on average, at the European level, 53\% of

\footnotetext{
${ }^{9}$ Named PERSE, this project focused on the "Performance of Social Enterprises" in the field of work integration. Funded by the 5th Framework Programme of the European Commission (DG Research), it was carried out in eleven EU countries from 2001 through 2004.
} 
WISEs' resources; of these 53\%, one third are socially motivated sales. Although this latter type of sales often appears to be vital for their economic equilibrium, WISEs may be reluctant to highlight their privileged relationship with the public sector. This is particularly the case when WISEs face accusations of unfair competition from the for-profit private sector.

Redistribution resources (direct and indirect subsidies) account for 38.5\% of resources. Subsidies are mostly linked to labour market policies and they primarily contribute to the funding of fixed-term contract employment or traineeship opportunities. Voluntary resources, which are most probably undervalued, represent on average 8.5 of total resources. This last kind of resource reflects the degree of embeddedness of WISEs in civic networks; social enterprises which are more strongly embedded in civic networks are usually better able to mobilise volunteer resources than social enterprises launched by public bodies. It finally has to be noted that this resource mix varies from one type of WISE to another, in accordance with their specific social mission; Social enterprises that produce social services for vulnerable users or those that integrate highly disadvantaged workers obviously need more non-market resources than other types of WISE.

\section{Conclusion}

European welfare states have a long tradition of partnership with third sector organizations even if the relationships vary according to the type of welfare mix (Evers \& Laville, 2004). The trends in development of social enterprises can be understood in a context of changing forms of government's support to third sector organizations and new emerging social needs resulting of the deep evolution of European societies. Social enterprises were pioneers in tackling social exclusion of various groups, especially in promoting their work integration through various models of WISE.

The historical perspective shows that these innovative entrepreneurial initiatives have contributed to the development of new public schemes and legal frameworks. Such public policies, however, have not been designed and implemented without raising important questions and strong debates. More precisely, the nature of social enterprises' mission appears to be a contested issue between promoters of social enterprises and public bodies. Public schemes often frame their objectives in a way that is considered as too narrow by some promoters with a risk of reducing social enterprises to the status of instruments to achieve specific goals which are given priority on the political agenda (Lemaitre et al., 2006). On the other side, it is clear that recognition through public policies has been and still is a key channel for the diffusion of various models of social enterprise throughout Europe.

Finally, far from relying only on income raised from the market, social enterprises seem to combine the economic principles of market, redistribution and reciprocity and to hybridize these three types of economic exchange so that they work together rather than in isolation from each other.

\section{References}

Bettio, F., \& Plantenga, J. (2004). Comparing care regime in Europe. Feminist Economics, 10(1), 85-113.

Borzaga, C. (2004). The third sector in Italy. In A. Evers J.-L. Laville (Eds.), The third sector in Europe, Cheltenham, UK. Northampton, MA: Edward Elgar.

Borzaga, C., \& Defourny, J. (Eds.). (2001). The emergence of social enterprise. London/New York: Routledge. (paperback edition: 2004).

Borzaga, C., \& Mittone, L. (1997). The multi-stakeholder versus the nonprofit organisation”, Discussion Paper 7. Trento: Dipartimento di economia, Università di Trento.

Borzaga, C., \& Spear, R. (2004). Trends and challenges for co-operatives and social enterprises in developed and transition countries. Trento: Edizioni31.

Davister, C., Defourny, J., \& Grégoire, O. (2004). Work integration social enterprises in the European Union: An overview of existing models, EMES working papers, no. 04/04. Liège: EMES European Research Network.

Dees, J. G. (1998). The meaning of social entrepreneurship. miméo: Stanford University.

Defourny, J. (2001). From third sector to social enterprise. In C. Borzaga \& J. Defourny (Eds.), The emergence of social enterprise (pp. 1-28). London/New York: Routledge.

Defourny, J., \& Nyssens, M. (2010). Conceptions of social enterprise and social entrepreneurship in Europe and the United States: Convergences and divergences. Journal of Social Entrepreneurship, 1(1), 32-53.

Defourny, J., \& Pestoff, V. (2008). Images and concepts of the third sector in Europe. EMES Working Papers, no 08/02. Liège: EMES European Research Network.

Defourny, J., Favreau, L., Laville, J.-L. (Eds.). (1998). Insertion et nouvelle économie sociale. Un bilan international, Paris: Desclée de Brouwer. DTI. (2002). Social enterprise. A strategy for success. London: Department of Trade and Industry. (www.dti.gov.uk/socialenterprise/strategy.htm). 
EMES. (2008). Social enterprise. A new model for poverty reduction and employment generation. Bratislava Regional Centre: United Nations Development Programme.

Esping-Andersen, G. (1999). Social foundation of postindustrial economies. New York: Oxford University Press.

Evers, A. (2010). Civicness and personal social services—-mapping a territory of discourses. In A. Evers, T. Brandsen, \& P. Dekker (Eds.), Civicness in the governance and provision of social services. NOMOS publishing house.

Evers, A., Laville, J.-L. (Eds.). (2004). The third sector in Europe. Cheltenham: Edward Elgar.

Gardin, L. (2006). A Variety of resource mixes inside social enterprises. In M. Nyssens (Ed.), Social enterprise—at the crossroads of market, public policies and civil society (pp. 111-136). London/New York: Routledge.

Hicks, A., \& Kenworthy, K. (2003). Varieties of welfare capitalism. Socio-Economic Review, 1, $27-61$.

Huber, M., Maucher M., \& Sak, B. (2008). Study on social and health services of general interest in the European union. Final synthesis report prepared for DG Employment, Social Affairs and Equal Opportunities (DG EMPL/E/4)-VC/2006/0131.

Hulgård, L., \& Bisballe, T. (2004). Work integration social enterprises in Denmark. Working papers series, no. 04/08. Liege: EMES European Research Network.

Kerlin, J. (2006). Social enterprise in the United States and Europe: Understanding and learning from the differences. Voluntas, 17(3), 247-263.

Kerlin, J. (2009). Social enterprise: A global perspective. Lebanon: University Press of New England.

Lemaitre, A., Laville, J.-L., \& Nyssens, M. (2006). Public policies and social enterprises in Europe: The challenge of institutionalization. In M. Nyssens (Ed.), Social enterprise (pp. 259-271). London/New York: Routledge.

Lewis, J. (1999). Reviewing the relationships between the voluntary sector and the state in Britain in the 1990's. Voluntas, 10(3), 255-270.

Mair, J., Robinson, J., \& Hockerts, K. (Eds.). (2006). Social entrepreneurship. New York: Palgrave Macmillan.

Netten, A., Darton, R., Davey, V., Kendall, J., Knapp, M., Fernández J.-L., et al. (2004). Understanding public services and markets, report commissioned by the King's fund for the care services inquiry. PSSRU Discussion Paper 2111/2 (pdf). Canterbury: Personal Social Services Research Unit, University of Kent.

Nicholls, A. (Ed.). (2006). Social enterpreneurship. New models of sustainable social change. Oxford: Oxford University Press.

Nyssens, M. (Ed.). (2006). Social enterprise-at the crossroads of market, public policies and civil society. London/New York: Routledge.

O'Hara, P. (2001). Ireland: Social enterprises and local development. In C. Borzaga \& J. Defourny (Eds.), The emergence of social enterprise. London/New York: Routledge.

O'Shaughnessy, M. (2006). Irish social enterprises: Challenges in mobilising resources to meet multiple goals. In M. Nyssens (Ed.), Social Enterprise (pp. 137-143). London/New York: Routledge.

Pestoff, V. (2004). The development and future of the social economy in Sweden. In A. Evers J.-L. Laville (Eds.), The third sector in Europe (pp. 6382). Cheltenham, UK/Northampton, MA: Edward Elgar.

Polanyi, K. (1944). The great transformation: The political and economic origins of our time. New York: Farrar and Rinehart.

Pollitt, C. (2007). Convergence or Divergence? What has been happening in Europe?. In S. Van Thiel \& V. Homburg (Eds.), New public management in Europe. Adaptation and alternatives (pp. 10-15). Basingstoke: Palgrave Macmillan.

Roelandts, B. (Ed.). (2009). Cooperatives and social enterprises. Governance and normative frameworks. Brussels: CECOP Publications 2009.

Salamon, L. M., Sokolowski, S. W., \& Associates (Eds.). (2004). Global Civil Society: Dimensions of the Nonprofit Sector, Volume 2. Bloomfield Conn.: Kumarian Press.

Stryjan, Y. (2004). Work integration social enterprises in Sweden. EMES Working Papers, no 04/02.

Stryjan, Y. (2006). Sweden: Social enterprises within a universal welfare state model. In M. Nyssens (Ed.), Social enterprise — at the crossroads of market, public policies and civil society (pp. 206-221). London/New York: Routledge. 